\title{
Two Otolaryngologic Cases of Munchausen's Syndrome
}

\author{
Munchausen Sendromlu \\ İki Otolarengolojik Olgu
}

Ediz YORGANCILAR, MD, Assis.Prof., ${ }^{a}$ Başaran DEMIR, MD, Prof., ${ }^{b}$

Sertaç AK, MD, Msc, ${ }^{\text {, }}$

İsmail TOPÇU, MD, Prof., ${ }^{a}$ Levent SENNAROĞLU, MD, Prof. ${ }^{\circ}$

aDepartment of Otorhinolaryngology and Head and Neck Surgery,

Dicle University Faculty of Medicine,

Diyarbakır

Departments of

bPsychiatry,

'Otorhinolaryngology and

Head and Neck Surgery,

Hacettepe University Faculty of Medicine, Ankara

Geliş Tarihi/Received: 07.12 .2010

Kabul Tarihi/Accepted: 12.05.2011

Yazışma Adresi/Correspondence: Ediz YORGANCILAR, MD, Assis.Prof. Dicle University Faculty of Medicine, Department of Otorhinolaryngology and Head and Neck Surgery, Diyarbakır, TÜRKIYE/TURKEY

edzyrg@hotmail.com doi: 10.5336/medsci.2010-22023

Copyright $@ 2012$ by Türkiye Klinikleri

\begin{abstract}
Munchausen's Syndrome is characterized by repeated attempts to be hospitalized following an extremely credible and dramatic representation of physical symptoms. This syndrome is commonly known as a factitious disorder. People with factitious disorders act this way not to achieve a concrete benefit, such as financial gain. Munchausen's Syndrome is often diagnosed after hospitalization. Early diagnosis is crucial for preventing high healthcare costs and facing ethical and legal problems. We believe that Munchausen's Syndrome related to otolaryngologic diseases is under-recognized and under-reported. In this article, two cases of Munchausen's Syndrome, genuine by their ear and nose factitious signs, are presented.
\end{abstract}

Key Words: Ear; ear diseases; nose; epistaxis; Munchausen syndrome

ÖZET Munchausen Sendromu, hastaneye yatış yapabilmek için aşırı derecede inanılır ve dramatik fiziksel semptomların gösterildiği tekrarlayan teşebbüslerle karakterizedir. Bu sendrom genellikle yapay bozukluk olarak bilinmektedir. Yapay bozukluğu olan insanlar maddi kazanç gibi somut bir fayda amacı gütmeden bu şekilde davranırlar. Munchausen Sendromu tanısı sıklıkla hastaneye yatışın ileri evrelerinde konulur. Yüksek sağlık hizmet bedelleri, etik ve yasal problemlerle karşılaşmamak için erken teşhis çok önemlidir. Biz otolarengolojik hastalıklarla ilişkili Munchausen Sendromu olgularının olduğundan az tanındığına ve bildirildiğine inanıyoruz. Bu makalede kulak ve burunla ilgili yapay bulgularla görülen iki Munchausen Sendromu olgusu sunulmuştur.

Anahtar Kelimeler: Kulak; kulak hastalıkları; burun; burun kanaması; Munchausen sendromu

Turkiye Klinikleri J Med Sci 2012;32(4):1179-82

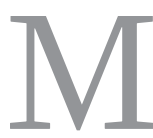
unchausen's syndrome (MS) is a rare condition in which the patient recurrently seeks medical care for a factitious illness. This syndrome was described by Asher. ${ }^{1}$ The disorder gains its name from Baron Karl Fredrich Von Munchausen (1720-97), a German aristocrat who told exaggerated stories of his travels and adventures in the Russian Army. Bursten described a triad of simulated illness, pathological lying (pseudologia fantastica) and wandering from hospital to hospital (peregrination) as the diagnostic criteria for MS. ${ }^{2}$ People with factitious disorders act this way because of an inner need to be seen as ill or injured; not to achieve a concrete benefit, such as financial gain.,4 MS by proxy was described in 1977 by Meadow, in which an individual fabricates or induces illness in a person under their care, typically a child. ${ }^{5} \mathrm{MS}$ is a risk to both the patient and the healthcare 
providers; all physicians should be aware of this disorder and properly care for afflicted patients. In this article, two cases of MS who have genuine aural and nasal symptoms and pathology are presented.

\section{CASE REPORTS}

\section{CASE 1}

A 19-year-old female admitted Hacettepe University Faculty of Medicine Otolaryngology Head and Neck Surgery Department. She was complaining of a history of recurrent simultaneous hemorrhage of her both ears. The hemorrhagehad occurred occasionally and there were not any other symptoms such as pain, hearing loss or vertigo. It was learned that the patient had admitted to another university hospital with similar complaints nearly 15 days before. The hematologic and radiologic tests performed in an attempt to localize the source of the aural bleeding at this university hospital were all negative. Past medical history revealed that the patient had an unknown ear surgery one year ago. Otologic examination revealed bilateral normal external auditory canals and intact tympanic membranes. The other physical examinations revealed no pathological signs. Hematologic tests and temporal bone computed tomography were all normal. A psychiatric consultation was obtained. The interview with the patient was made by the help of her brother, because she was unable to speak Turkish. In psychiatric examination, the patient's consciousness was clear, cooperation and orientation were normal. Her mood was euthymic but her affect was inappropriate to the current situation; she was smiling while describing her complaints. She did not have any psychotic symptoms. She said that, she made a trauma to the both of her external auditory canal with a sharp device nearly 5 months ago. After this trauma, bilateral recurrent hemorrhage began. From her history we also learned that the hemorrhage occurred at the same time with her menstrual bleeding. We thought that this hemorrhage was made by the patient herself. After appropriate explanations were given about the disorder (MS), the patient accepted that the her ear-hemorrhages were simulated by herself with her own menstrual blood. Therefore, we diagnosed the patient with MS.

\section{CASE 2}

A 16-year-old female admitted Hacettepe University Faculty of Medicine Otolaryngology Head and Neck Surgery Department. She was complaining of a history of recurrent epistaxis and simultaneous hemorrhage at her both ears. The epistaxis was occurring occasionally without any related conditions such as trauma, effort or menstrual cycle. She was hospitalized at another university hospital three months ago. The hematologic and radiologic tests were performed at this university hospital. All tests were normal. On anterior rhinoscopy, they observed an ulcerative lesion on the Little area of her nasal septum. They performed a chemical cauterization to control the bleeding. A punch biopsy was made from this area for differential diagnosis. The histopathologic examination of the punch biopsy was reported as "chronic inflammation". The case admitted to Hacettepe University Faculty of Medicine Otolaryngology Head and Neck Surgery Department. Otolaryngologic examination revealed blood clots in the external auditory canal. Rhinologic examination was normal. Hematologic tests revealed only hypocromic microcytic anemia. Radiologic and audiologic tests were all normal. A child psychiatry consultation was obtained. In psychiatric examination, the patient's consciousness was clear, cooperation and orientation was normal. There was no pathological sign in her speech and thought process. Her mood was euthymic. She did not have any psychotic symptom. She was calm while describing her complaints. Throughout the course of treatment, a bloody injection needle was found near her bed that was not used by the hospital staff. After appropriate explanations were given about the disorder (MS), the patient accepted that she caused bleeding by digital trauma and her own blood. Therefore we decided that the diagnosis of the patient was MS.

\section{DISCUSSION}

Our MS cases remind the otolaryngologysts of two important points. First, etiology of aural bleeding can be MS in which aural bleeding is simulated by the patients's own menstrual blood; second, the lesion on the Little area of nasal sep- 
tum and recurrent epistaxis can be caused by MS. We believe that, all MS patients with different symptoms must be reported. These reports will be helpful for diagnosis of similar MS patients in the future.

The true incidence of MS is unknown. Unfortunately, the prevalence of MS is difficult to determine; patients with this disorder do not always diagnosed correctly. There have been no specific studies that have specifically assessed the prevalence of MS. Prevalence of factitious disorders is probably in the range of $0.2-1 \%$ in hospital in-patients. ${ }^{6}$ We suppose that the prevalence of MS is reported less than it actually is.

MS is rare in otolaryngologic practice and a only afew cases have been reported in the literature. Pender and Pender first reported a male with MS who again and again presented with feigned airway distress and expectoration of blood achieved by biting his own cheek. ${ }^{7}$ In 1983, Winans et al. described a case of MS involving a self-induced orbital emphysema. ${ }^{8}$ Zohar et al. described five cases of MS, presenting with otolaryngologic symptoms. ${ }^{3}$ Two of these cases were MS by proxy. Mra et al. presented a case of MS by proxy in a 3-year old female, who initially presented with recurrent meningitis after head trauma and persistent cerebrospinal fluid otorrhea. ${ }^{9}$ Her mother was apparently soaking the surgical dressings with cerebrospinal fluid. Cerebrospinal fluid was obtained through a lumbar drain. In 2001 Griffiths et al. described a case of MS by proxy presenting with persistent aural bleeding, which is an uncommon symptom of chronic suppurative otitis media. ${ }^{10}$ This aural bleeding was the result of trauma inflicted by child's mother. In 2005, Bennett et al. presented a case of MS by proxy in which the child's mother spat and placed blood in her sons's ear. ${ }^{11}$ Gozlukaya presented a case admitted to emergency unit with aural bleeding. ${ }^{12}$ Persistent aural bleeding in the absence of granulation tissue should arise suspicions of MS or MS by proxy. Our first case was the second reported case with aural bleeding, who placed her own menstrual blood into her ear. In our second case, digital trauma to her own nose resulted to recurrent epistaxis. In the litera- ture this case was the first case of MS with epistaxis which resulted from digital trauma.

In the management of MS, the first step must always be suspicion. These patients can present with many different complaints and clinical symptoms. The patient's history and physical examination can be very helpful in diagnosis. In our first case, history of aural bleeding was simultaneous with the patient's menstrual cycle, and this was very helpful in diagnosis.

The differential diagnosis of MS must be made with other psychiatric disorders. Conversion disorders, hypochondriasis, malingering, somatization disorders and MS by proxy are to be considered. ${ }^{13}$ People with MS know that they cause their symptoms themselves and can be highly manipulative, but their behavior brings them no obvious benefit. Primal motivation of these patients is to get hospitalized and this is almost a life style for them. The patient suffering from MS or Munchausen by proxy (mostly children) have no clear gain and Munchausen patients actively seek hospitalization and invasive painful procedures simply to undergo them. People who malinger pretend to be ill to gain some sort of benefit, such as avoiding military duty or trying to obtain compensation. The people with somatization disorders have symptoms that cannot be medically explained but their symptoms are not deliberately produced. Hypochondriac patients present with anxiety as the main symptom and either no physical signs are present or physical signs are medically insignificant.

The treatment of MS is difficult, and it requires the help of a psychiatrist. Treatment is usually challenging, and there are no clearly effective treatments. Early detection will allow proper psychiatric referral to prevent injuries to the patient, abuses to the medical system, and unnecessary operations. We suggest that recognition of MS is not only important for proper medical diagnosis and treatment, but also essential in protecting the patients from invasive and aggressive medical procedures.

Prognosis of MS is very difficult to predict due to difficulty of tracking these patients and therefore the lack of follow-up studies. 


\section{CONCLUSION}

Two cases of MS related to otologic and rhinologic disease were presented. Munchausen syndrome must be suspected whenever persistent and recurrent unexplained illness afflicts a case.
We believe that MS related to otolaryngologic diseases is under-recognized and under-reported. We report these cases in the hope that otolaryngologysts will more easily recognise similar patients affected by the MS, avoiding invasive procedures.
1. Asher R. Munchausen's syndrome. Lancet 1951;1(6650):339-41.

2. Bursten B. On Munchausen's syndrome. Arch Gen Psychiatry 1965;13:261-8.

3. Zohar Y, Avidan G, Shvili Y, Laurian N. Otolaryngologic cases of Munchausen's syndrome. Laryngoscope 1987;97(2):201-3.

4. Özcan CC, Akyüz G. [Factitious disease in children: case report]. Turkiye Klinikleri J Pediatr 2008;17(1):47-50.

5. Meadow R. Munchausen syndrome by proxy. The hinterland of child abuse. Lancet 1977;2(8033):343-5

6. Lauwers R, Van De Winkel N, Vanderbruggen $\mathrm{N}$, Hubloue I. Munchausen syndrome in the

\section{REFERENCES}

emergency department mostly difficult, sometimes easy to diagnose: a case report and review of the literature. World J Emerg Surg 2009;4:38

7. Pender DJ, Pender VB. Otolaryngologica prevarica: Munchausen's syndrome update and report of a case. Laryngoscope 1980;90(4): 657-60.

8. Winans JM, House LR, Robinson HE. Self-induced orbital emphysema as a presenting sign of Munchausen's syndrome. Laryngoscope 1983;93(9):1209-11.

9. Mra Z, MacCormick JA, Poje CP. Persistent cerebrospinal fluid otorrhea: a case of Munchausen's syndrome by proxy. Int J Pediatr Otorhinolaryngol 1997;41(1):59-63.
10. Griffiths $\mathrm{H}$, Cuddihy PJ, Marnane C. Bleeding ears: a case of Munchausen syndrome by proxy. Int J Pediatr Otorhinolaryngol 2001;57 (3):245-7.

11. Bennett AM, Bennett SM, Prinsley PR, Wickstead M. Spitting in the ear: a falsified disease using video evidence. J Laryngol Otol 2005;119(11):926-7.

12. Gozlukaya A. [A case of Munchausen syndrome admitting with hemorrhage]. Journal of Academic Emergency Medicine Case Reports 2010;(1):47-9.

13. Robertson MM, Cervilla JA. Munchausen's syndrome. Br J Hosp Med 1997;58(7):30812. 